\title{
Cyprus and Europe: Geo-economics of a Relationship or Putting the "Periphery" into Context
}

\author{
Alper Arisoy $^{1}$ \\ ${ }^{1}$ Faculty of Business, Dokuz Eylul University, Turkey \\ Correspondence: Alper Arisoy, DEU Faculty of Business Kaynaklar Campus, 35160 Buca Izmir, Turkey. Tel: \\ 90-532-587-5265. E-mail: alper.arisoy@deu.edu.tr
}

Received: September 1, 2014

Accepted: September 15, 2014

Online Published: September 18, 2014

doi:10.5430/rwe.v5n2p198

URL: http://dx.doi.org/10.5430/rwe.v5n2p198

This study is the revised and extended version of the paper presented at the conference titled: "The East Mediterranean and Cyprus: Economic and Political Relations: Cooperation and Integration from Past to Future", which was organised on 15-16 December 2010 by Girne American University Faculty of Business and Economics.

\begin{abstract}
Mostly referred to as "crossroads", "stepping stone" or an "outpost", the island of Cyprus is characterized by some sui generis features that differentiate it from most of other insular settings in the Mediterranean. The most interesting of these features is the fact that this third biggest island of the Mediterranean is located at the center of a triangular area formed by the ancient centers - or cores - of the Mediterranean world, namely: Egypt, Mesopotamia and the Aegean basin. Despite this "central" position within the Eastern Mediterranean, the island seems to be "peripheral" with regard to each of these ancient centers, or core areas. A similar geo-economic relationship seems to be the case today with the "core" area of Europe. Departing from this background, the purpose of this paper is to assess the nature of the relationship between Cyprus and Europe, with particular respect to historical turning points and changing geo-economic settings, through which this relationship has evolved. Accordingly, the main questions to be addressed are as follows: is the core-periphery relationship between Cyprus and Europe different from the previous forms of peripherality of Cyprus? If so, in which respects? Drawing upon some basic concepts such as core-periphery dichotomy, insularity, isolation and connectivity, the main argument of the paper is as follows: while the core area of the Mediterranean - and eventually the world economy - shifted towards North-west Europe, the center of gravity of the island, towards which the geo-economic activities of the island tended, has also started to shift. The island has turned into a periphery of this new core. However, this shift brought about also a change in the pattern of peripherality. Accordingly, the island's position with regard to Europe as its extension has been formed within the center- or core-periphery context, within which mostly political and strategic - rather than economic concerns played part.
\end{abstract}

Keywords: Cyprus, Europe, Mediterranean, core, periphery, economic geography

\section{Introduction}

Within the Mediterranean world, what differentiates Cyprus from other major islands is the fact that this third island of the Mediterranean is located at the center of a rough triangular area, angles of which correspond to Mesopotamia, Egypt and the Aegean Basin. While geo-economic supremacy among these core-areas shifted, the relationship of Cyprus with regard to these regions has evolved as well. As the longest-standing geo-economic core within the Eastern Mediterranean turned out to be the Aegean basin, the island eventually became an extension of the Aegean, including Balkans and Asia Minor. But in all cases, qualified as a point of passage, crossroads or stepping stone, Cyprus remained "peripheral" with regard to these altering core areas located around itself. In other words, as it was peripheral to Mesopotamia or Egypt once, it was also peripheral to the Aegean world. The further changes within this setting had also direct impact on the island. For instance, when the supremacy of the Aegean was taken over by Romans who eventually settled within this area, the island sustained its peripheral status with regard to the core area of the Roman/Eastern Roman Empire. The same setting went on during the Venetian and Ottoman rules. This pattern of center- or core-periphery relationship between Cyprus and the geo-economic centers of gravity started to change substantially with the rise of the Northwestern Europe as the new core of the old world and eventually the world economy. During this process, the Aegean basin, which had been the geo-economic core itself for hundreds of years, 
started to become peripheralized with regard to the Northwestern Europe. As a result of this process, Cyprus also became the periphery of another geo-economic core, i.e. the Northwestern Europe. The questions that emerge at this point are as follows: is this new form of core-periphery relationship between Cyprus and Europe different from the previous forms of peripherality of the island? If so, in which respects? Given that this center- or core-periphery relationship seems to continue within the European integration as well, the island being classified as periphery, might this relationship suggest a revisiting of the bases for Cyprus's European affiliation? Of course, especially in the context of European Integration in which the island has been involved for over a decade now, this affiliation seems so natural and clear that one could hardly dare to question Cyprus's being part of Europe. However, let alone the specific geopolitical conditions of Cyprus and its relations to the rest of the Mediterranean world, even the long-discussed question of "where does Europe end?" suggest a closer look on the peculiar nature of the relations between Cyprus and Europe. Thus, rather than questioning the Cyprus's - rather evident - Europeanness, the main purpose of this paper is to assess the nature and the main features of the relationship between Cyprus and Europe, re-formulating the afore-mentioned question as "Where - and how - does Europe extend?"

In order to address the above-stated questions, firstly the concepts of insularity, isolation and connectedness will be accounted for, with particular reference to Cyprus's sui generis characteristics as a Mediterranean island. Then, to complement the conceptual framework, the so-called core-periphery dichotomy will be revisited as far as required by the context of this paper. After having thus clarified the basic concepts and the way they are utilized in this paper, the basic characteristics of the island of Cyprus will be assessed by means of these concepts. In the last part, Cyprus's position with regard to the core-periphery interplay throughout history and changing patterns of peripherality will be accounted for. In this part, historical background will be diachronically outlined from very early periods onwards, thus expecting to provide hints of structural features of the geo-economics and geo-politics of the island. Here, a particular reference will also be made on the role and place of Cyprus in Europe's relations with the Levant and the Near East. It will be argued that while the core area of the Mediterranean - and eventually the world economy shifted towards Northwest Europe, the center of gravity of the island has also started to shift. This shift brought about also a change in the pattern of peripherality, which transformed the island into an "extension" - if not an outpost - of Europe. This main argument will be elaborated through geopolitical and historical perspectives as well as drawing back to the constructive - and de-constructive - approaches on the question of Europe's frontiers.

\section{Insularity: Isolation vs. Connectivity}

As a huge amount of water posing numerous challenges to overcome, at first sight, the sea seems to be a geographical obstacle and hence a perfect determinant of natural borders of lands surrounded by, or located around itself. However, the knowledge of navigation makes a perfect environment of communication and interaction out of sea, which becomes a field in itself, bridging the distant shores and cultures. Needless to say, the main impetus for navigation has been trade and the Mediterranean basin has formed a perfect example of such an interaction. From time immemorial, the immediate surroundings of the Mediterranean Sea have formed a common area of culture and civilization (Braudel, 1999: 57-80). Some expressions such as "internal sea", "Mare Nostrum", etc. all imply unity and centrality of this part of the world, the unification being centered on the sea both in material and cultural terms.

On the other hand, although at first sight it might look contradictory - or paradoxical(ly complementary), besides trade, this area has almost always been characterized by constant conflicts. Therefore, the sea and insular pieces of lands have also served as refuge throughout history, especially for those inhabiting the littoral areas. Especially in the Middle Ages, this dimension of the sea was so crucial that as Alcuin put in a didactic manner, the answer to "what is sea?" (quid est mare?) was given as "a refuge in time of danger" (refugium in periculis). This motto, chosen as an epigraph to enlighten the very origins of the Venetian state, also characterizes the ensuing nature of the Venetian politics, economy and diplomacy across the Mediterranean (Brown, 1887: 2). Thus, it is no coincidence that also the island of Cyprus once served as a "refuge" for Venetians in the Eastern Mediterranean. This argument, which will be further elaborated below, suggest the paradoxical nature of being on an island, i.e. both being isolated from surroundings, and being within reach of very distant shores linked by maritime activity. It is out of this setting that the peculiar nature of Cyprus's relation to Europe emerges.

Insularity reflects certain seemingly contradictory and paradoxically complementary aspects: on the one hand isolation (Note 1) and hence autonomous features, on the other hand barren lands and hence dependency on the "terra firma". It is out of these aspects that the above-stated function of "refuge" arises. In the case of Venice, early history of which was shaped by the idea of taking refuge in the islands of Laguna in the face of external threats, geographical-topographical constraints eventually led to dynamism, which ended up in a maritime empire. In the Aegean islands, structural geo-economic dependence on the mainland and scarcity of natural sources, agriculture etc. led the inhabitants to maritime activity, eventually giving rise to huge trade fleets and de-facto economic independence. Thus, despite their differing levels of isolation, islands are at the same time strikingly exposed to 
interaction and they are intricately linked into broader social, cultural, and politico-economic networks, serving as nodes where maritime communities meet and communicate, and where long-distance trading networks and island alliances form and develop (Knapp, 2008: 20).

Reflected by these examples, the curious nature of insularity, referred to as "island paradox" (Knapp, 2008: 20), is accounted for by Braudel in following terms:

'Isolation' is a relative phenomenon. That the sea surrounds the islands and cuts them off from the rest of the world $[\ldots]$ is certainly true whenever they are really situated outside the normal sea routes. But when they are integrated into shipping routes and $[\ldots]$ become one of the links in a chain, they are on the contrary actively involved in the dealings of the outside world, less cut off from them than some inaccessible mountain areas (Braudel, 1972: 50).

It is out of this context that the concepts of "connectivity" and "isolation" emerge, forming the backbone of the island paradox (Constantakopoulou, 2007: 1). Connectivity, which means island-mainland or inter-island relations involving mobility, trade and exchange (Knapp, 2008: 8, 14) is a matter of degree, with regard to isolation. Accordingly, geo-economic position of an island can shift from isolation to connectivity, in line with changing conditions of the overseas centers, trade-routes, geo-political and geo-economic transformations etc. Thus, balance between connectivity and isolation can change from region to region and through time within a region. Although an island does not change its location, what happens in the distant shores have direct impact on the degree of its connectivity. It is quite obvious that thanks to developing transportation facilities, over the continuum between isolation and connectivity, the overall trend is towards the latter (Broodbank, 2000: 10). However, while the overall degree of connectivity increases, relative connectivity might change in accordance with the altering centers of gravity. In other words, following shifting patterns of core-periphery relations, an island's core area, to which it is geo-economically dependent can change over time.

Needless to say, the case of Cyprus offers a representative example for the above-stated arguments. In order to assess these arguments in the context of this island, it seems necessary to have a closer look at the historical and geo-economic aspects of Cyprus's position in the Mediterranean world. But before this, one should review the concepts of core, periphery and center of gravity, in order to complete the conceptual framework.

\section{Centrality and Core - Periphery Dichotomy}

For the sake of the arguments here, some basic concepts such as centrality, center of gravity, core and periphery need to be re-defined - or re-visited - with regard to the specific context of this paper. What we mean by centrality here comprises both the concepts of "center of gravity" and "core area", and hence it is also an integral part of the core-periphery dichotomy. Below, firstly this latter will be discussed, trying to formulate a definition limited to the context of this paper. Then the term "center of gravity" will be clarified. Thus, definitions and clarifications under this title should be regarded as context-based attempts of disambiguation.

Originally formulated by Prebisch as "a description of the axial division of the labor of the world-economy" (Wallerstein, 2006: 28, 93) and further developed by Wallerstein, core-periphery dichotomy forms the backbone of the world-system approach. Accordingly, international economic system is made up of an industrial center and its agrarian periphery. Economically powerful center dominates the periphery, leading to unequal exchange between the core and periphery (Love, 1980: 45). Higher-skill and capital-intensive production as well as strong state mechanisms characterize the core areas, which appropriate much of the surplus of the whole "world-economy" (Wallerstein, 1974b: 401). On the contrary, low-skill, labor-intensive production and weak political structures characterize the peripheral areas, from where raw materials are transferred to the core areas. The areas located in between like "buffer zones" fall under the category of semi-periphery (Wallerstein, 1974a: 349-350; Wallerstein, 2006: 29). According to this classification, while Northwest Europe has emerged as the core of the world economy from the early modern period onwards, most of the southern hemisphere and Eastern Europe formed the periphery. In this setting, south or "Mediterranean Europe" was classified as semi-periphery (Wallerstein, 1974b: 400-401). It is with reference to this theoretical background that "Southern Europe", as well as "Southeastern Europe" started to be used for the less developed parts of the continent, rather than mere geographical connotations (Koliopoulos \& Veremis, 2010: 202).

Classified under structuralism (Brown, 1997: 56-57, 188-189, 200), these arguments focus on the dynamics of production and labor relations. Hierarchical division of labor was based on a rough classification of geographically distinct parts (Wallerstein, 1974a: 349-350), but core and periphery represent just the spatial setting of production and labor relations, rather than pure geographical categories (Wallerstein, 1974a: 349). Accordingly, the fact that "the range of economic tasks is not evenly distributed throughout the world-system [...] is a function of the social 
organization of work" (Wallerstein, 1974a: 349). It is at this point that the terms "core" and "periphery" should be redefined with reference to the context of this paper, as they are used with a slightly different set of meanings than the above-explained approach. Accordingly, the term "core" can shortly be defined as an area of attraction located around a center of gravity. It is characterized by a multitude of hubs, i.e. nodes of transportation, circulation and communication networks. This attraction - or gravitation - stems basically from geographical position, hence from physical geography. Accordingly, physical geography, i.e. location of mountains as natural barriers, rivers as water sources, and riverbeds as natural corridors all contribute to the formation of human geography, which in turn determines the economic geography. Thus, it is not just the production and labor relations that form the core area. Within the context of this study, a core area is above all a geographical category, formation of which basically depends on the communication and transportation networks as well as climate and agricultural characteristics. In the same sense, surroundings of the core area gradually fall under the category of "periphery", which economically depends on and also tends towards the core.

Needless to say, although deeply influenced by physical geography, which hardly changes over time, geo-economic core can change, or even transform into periphery due to the changing of main routes, networks, types of production, use of technology or political factors. In other words, although physical geography seems to be crucial in the formation of a geo-economic core, centrality itself is not something deterministic, it is subject to shifts and alterations over time.

At this point, another disambiguation might be needed for the use of the term "center of gravity". In the context of this study, a center of gravity refers to a region located at the heart of a core area. Intensification of hubs as urban agglomerations, ports, crossroads etc. transform an area into a center of gravity, towards which labor, goods, capital etc. tend to flow. In other words, a center of gravity refers to the most active part of a core area and both these concepts together form the rather rough and a bit more abstract concept of "centrality".

Thus, what is meant here by center of gravity refers rather to a region involving various kinds of networks, than a focal point or a smaller area resembling the concept of fulcrum in physics. This second meaning has become especially popular in the globalization debate, paving the way for various methods of measurement of world's economic center of gravity (WECG) (Grether \& Mathys, 2009: 47). Based on the concept of center of mass (or gravity) in physics, and replacing the mass with production, this concept refers to the focal point in the Earth's spherical volume, at which the spatial distribution of global economic activity is at average (Grether \& Mathys, 2009: 47; Quah 2010: 6; Quah, 2011: 3). An exhaustive mapping of global economic activity seems impossible (Quah, 2010: 1) because of multitude of variables influencing and determining economic activity. But still, econometric analyses taking into consideration even only urban agglomerations or GDP yield interesting results. In this sense of the term, center of gravity does not refer directly to the center or core area of the world economy, but it indicates it. A diachronical analysis enriched by extrapolations towards future indicates also the way core area shifts over the globe, as suggested by Quah (2011). Accordingly, as of 1980, world's economic center of gravity (WECG) was located at a point somewhere in the middle of the Atlantic Ocean, which by 2008 had shifted to a point around Izmir, indicating the constant rise of East Asia (Quah, 2011: 3-9). Extrapolating this trend to 2050, Quah suggests that the center of gravity point will end up somewhere between India and China then (2011: 9).

Although this wider and more popular use of the term is out of the scope of this paper, it provokes a little detour, which in turn might contribute to our basic arguments. Accordingly, as will be explained below, Cyprus's position within the Mediterranean corresponds to a place, which is located in the middle of the three ancient central areas namely Mesopotamia, Egypt and the Aegean basin. This literally central position brought about peripherality for the island vis-à-vis each of these centers. However, if one takes the term "center of gravity" in the aforementioned meaning referring to a point rather than an area of economic activity, maybe the island of Cyprus might turn out to be the center of gravity of the Eastern Mediterranean for most of the pre-modern period. A study involving a variety of data on production, trade volume, number of ships etc. processed by means of an econometric analysis might have been quite interesting to read. If it included the changes over a time span towards recent centuries, it might have also been connected to the overall global transformations exceeding the limits of the Mediterranean. Unfortunately neither physical nor contextual scope of this paper permits such an attempt, let alone the lack of sufficient data and necessary theoretical and technical tools to process them. Therefore, we will continue rather with a brief account of Cyprus's sui generis characteristics stemming mainly from its physical geography and location.

\section{Peculiarities of Cyprus: A Periphery in the Middle}

As an island, Cyprus shares many of the above stated generic features of the islands dispersed around the Mediterranean. As a matter of course, it also reflects the consequences of insularity. However, additional to these 
general traits of islands, certain factors give Cyprus some more idiosyncratic characteristics that make it a unique case in the Mediterranean. These characteristics are its spatial extent and natural resources, which has fostered a traditional pattern of self-sufficiency and its location at crossroads of the Mediterranean.

In the first place, as the third biggest island in the Mediterranean (following Sicily and Sardinia) Cyprus stands out because of its spatial extent, natural resources and geographical configuration (Knapp, 2008: 3). Its spatial extent, dimensions and the breakdown of mountainous and plane lands provide the island (unlike many islands in the Mediterranean) with relatively sufficient water supplies and agriculture areas. These features in turn not only pave the way for self-sufficiency for the islanders, but also lay the foundations of an export-based economy deriving mainly from agriculture, as well as other natural sources such as copper ores and salt reserves.

It is on the base of this setting that, from the very early phases of human settlement on its soil, Cyprus has been marked by an original island culture distinct from its surroundings. It seems that this pattern, especially the self-sufficiency continued to exist right into the early modern period (Note 2).

The second characteristic of Cyprus, which distinguishes it from other Mediterranean islands, is its location. The "strategic location" of the island is widely referred to, but what concerns us here somewhat exceeds the limits of this rather cliché argument and touches a particular aspect of its geographical position. Accordingly, Cyprus is located in a way at the "center of the centers" of the Mediterranean world, which are as follows: Mesopotamia, Egypt and the Aegean basin. These three centers of gravity, each of which came to the fore during the crucial periods of the Mediterranean history laid the foundations of the Mediterranean civilization. To these classical centers, one should also add the core of the above-stated world economic system as the fourth one, with which the island developed close relations. As will be seen below, much before the rise of this modern core, Cyprus had already close ties with Western Europe. Therefore, one might argue in a sense that, despite its position in the eastern end of the Mediterranean, Cyprus is located virtually in the middle of this sea. Probably it was due to this position of being "in the middle" that Ottoman geographer and cartographer Pirî Reis described Cyprus in early $16^{\text {th }}$ century as "an island remained in hesitation" in between the major powers of the era (Pirî Reis, 2002: 768). Probably again it is upon this peculiarity of the island that Cyprus is qualified as not being "properly" in the Levant (Demand, 2004: 257).

Needless to say, it was due to this peculiar position that the island has always been a point of transition and interaction among the cultures of the Mediterranean. As early as the Bronze Age, this interaction at the crossroads of east-west sea routes involved three main elements: the Aegean Minoan-Mycenaean, the local Cypriot, and the Phoenician (Demand, 2004 257, 265). Among these, the role of the Aegean turned out to be the most important, as from the very early periods onwards the island had become and remained an extension of the Aegean world. Especially after emergence and spread of the Ionian civilization, Cyprus became an outpost - or periphery - of this area of civilization (Raaflaub, 2004: 203, 205) functioning still as a contact point between the Near East and the Aegean, transmitting the information of the Near East to the newly emerging Aegean world (Raaflaub, 2004: 205).

At this point, a clarification might be needed as to the role of the Roman Empire and whether Rome (and the Italian peninsula) might also be seen as another center of gravity exercising influence on the island. As known, Rome emerged as a political power at the western margin of the Aegean world, which comprised not only littoral parts of Anatolia and South Balkans, but also South Italy. Then, not only it assumed the cultural legacy of the Aegean world, but from $4^{\text {th }}$ century onwards it carried its capital city to the new center of this world, transforming Byzantium into "New Rome". Consequently, Aegean world itself experienced a shift of center within itself, from classical metropolitan centers such as Athens and Ephesus to present-day Istanbul. In this context, Rome should also be regarded as part of the Aegean world, taken in the wider sense of the term. Thus, following Mesopotamia and Egypt, the Aegean became the last and the longest-lasting geopolitical unity up until the $20^{\text {th }}$ century (Inalc1k, 2012: 2). But needless to say, other ancient centers kept their crucial positions, albeit as remote extensions of Roman, Byzantine or Ottoman Empires.

In any case, the island of Cyprus remained connected to these centers as well as to the western half of the Mediterranean, because as stated above, even before the emergence of the modern core area in Northwest Europe, island had already become part of the remote maritime networks of Western Europe.

The peculiarity of Cyprus's relationship to Europe arises in this setting. Accordingly, from the emergence of European trade centers onwards, island's commercial relations with Western Europe have been as intense as those with its immediate surroundings. For certain periods such as late medieval kingdoms or the British rule, the island became a direct extension of Western Europe. On the other hand, most of its history passed in close connection with the Aegean basin and formed by the developments in this area. In that sense, for most of its history, the island remained as periphery of the Aegean as well. These arguments, which at first sight might seem paradoxical - if not 
contradictory, will be further elaborated with an overview of Cyprus's position in the core-periphery interplay as well as its relationship with Europe.

\section{Cyprus in the Centre - Periphery Interplay}

As stated above, the island of Cyprus has always been a hub of trade and transport due to its favorable position at the crossroads of maritime routes. As early as the late Bronze Age, the island had established overseas trade relations and its interconnections with the outside world focused especially on Egypt. The wealth brought about by trade during this period was based on copper and olive oil production, as well as manufacture of vases for the export market (Hadjisavvas, 2007: 548). In fact, it was during the course of the period referred to as Bronze Age (ca. 2700/2650-1100 BC) that the island underwent a transformation from an isolated, village-based culture into an international, town-centered, perhaps even state-level polity (Knapp, 2008: 1). Although main factors of these developments differ greatly, island's central location with reference to its surroundings as a nodal point of trade seems to be the most crucial one.

As stated briefly above, island's position has changed through ages in accordance with the shifting of centers of gravity in the Mediterranean. But what is for certain, from the earliest periods to the wake of modernity, except for certain periods of conflicts, the island had flourishing trade relations with the outside world. As early as the first years of the $16^{\text {th }}$ century, British ships were carrying English cloth to Crete, Cyprus and Syria in exchange for silks, spices, oils, carpets and mohair yarn (Wood, 1964: 2). Except for the periods of armed conflict, especially between the Ottoman Empire and the Venice, trade in this area was carried out without obstacle (Wood, 1964: 3-4). Shortly after the conquest of the island by Ottomans, which brought the end of Venetian rule in the area, trade relations were rearranged. For centuries, Venice had played the role of bridge between eastern and western parts of the Mediterranean world. Decline of this maritime empire brought about a temporary decline in the Mediterranean trade as well. It was in this setting that, Western European countries started to establish direct trade contacts in the region. This period also corresponds to the rise of the modern core in Northwest Europe. At the end of the decade following the conquest of Cyprus by the Ottoman Empire, certain merchants of London were incorporated as the Turkey Company, laying the foundations of the Levant Company. On the expiry of the patent granted by Queen Elizabeth in 1588, the Turkey Company's patent was not renewed due to a conflict of interests with the Venice Company, founded in 1583. In 1592 both companies were merged together as the Levant Company, which arranged the British Isles' trade relations with the region up until its dissolution in 1825 (Luke, 1921: 86-87). This Company, during its lifetime, appointed and paid all the British consuls and consular offices in the Ottoman Empire (Luke, 1921: 99). It was due to increasing trade relations and the role of Cyprus that western European countries started to appoint diplomatic representatives on the island. Although existence of a British vice consul on the island is traced back to 1626, the first regular appointment of a consul occurred in 1636 (Luke, 1921: 88). According to Turkish sources, the first consulates opened on the island were of France, Britain and Venice (Özkul, 2010: 112). During the following decades Netherlands, Holy Roman Empire, Sweden, Kingdom of Two Sicilies and the Republic of Ragusa had also appointed consuls to Cyprus, all of whom were located in Larnaca (Özkul, 2010: 112). Among them, the most active ones were the British and the French, due to the intensity of trade with their respective countries (Özkul, 2010: 113). French Levant Company was particularly active on the island throughout the $17^{\text {th }}$ century, whereas British Levant Company's "factory" (trade center) in Cyprus rose into importance during the $18^{\text {th }}$ century (Luke, 1921: 89-90). The history of Company sheds light on the intertwined natures of trade, diplomacy, politics and conflicts in the region. As Britain's interests in the region were mostly trade-related up until the $19^{\text {th }}$ century, the Company, founded by a royal charter both financing and appointing consuls in the Ottoman Empire, was acting as the diplomatic extension of British Isles in the region. The role of the company in diplomatic setting was to such an extent that the seal used on official consular documents bore not the British but the Company's arms (Luke, 1921: 99). Later on, due to the growing complexity of Ottoman Empire's political relations with Western Europe, British representatives in the Empire were made directly responsible to their government and the Levant Company was dissolved (Luke, 1921: 102).

This overview of Cyprus's trade connections and its relations with centers and core areas can be enriched by a closer look into the major export goods and relevant figures. Between $16^{\text {th }}$ and $20^{\text {th }}$ centuries, the most important export products of Cyprus were grain, wine, seeds, locust-beans, cotton, madder roots, silk and salt. Hamilton Lang, who served in Cyprus during 1860s and 70s as the vice consul and consul of Britain reports that, while the area allocated for grain production amounted to around $350 \mathrm{sq} . \mathrm{km}$. (87.000 acres) in 1844, he estimates that as of 1878 around 450 sq. km. (112 acres) was used for grain production, mainly for barley and wheat (1878: 224). Drawing upon a previous consular report, Lang writes that in 1862, while wheat production of the island estimated to be around 1500 tons (120.000 quarters), barley produced on the island was estimated at 2.250 tons (180.000 quarters) (1878: 224-225). In fact, during this period agriculture was reported as on the increase, both in area and quality, the tithes having increased more than one third in amount from 1865 to 1872 (Fisher, 1878: 72). 
Island's cotton supply to Europe, which had already been of considerable amounts under the Venetian rule (Lang, 1878: 229), continued during the Ottoman period. Along with Izmir, the island was the chief supplier of cotton for Manchester manufacturers during the first half of the $17^{\text {th }}$ century. In this period, the cotton of Cyprus was transferred to British Isles by means of the factory of the Levant Company. Therefore, Cyprus is referred to as "a very early contributor to the wealth of Manchester" (Lang, 1878: 228). As far as the British textile industry is concerned, another contribution of the island - along with Izmir, Naples and Syria - was the madder root, out of which the red color referred to as "Turkey red" was extracted. The article was largely exported to Britain by the Levant Company and it was only from the last quarter of the $19^{\text {th }}$ century onwards that the exports started to decrease due to the development of cheaper ways for dying textiles (Lang, 1878: 234-236). A related branch of industry was printing of British calicoes, which were in high demand in the Ottoman Empire. Albany Savile reports that towards mid- $19^{\text {th }}$ century, there was an intense trade of these articles, and numerous establishments located around Nicosia were printing British calicoes in bright colors for divan and quilt covers, window blinds etc., which were exported in great quantities to Istanbul, Izmir and Syria (1878: 144). Drawing on consular reports, Savile writes that during the second half of the $19^{\text {th }}$ century, this industry started to decline due to high exportation duty charged upon the articles (1878: 144)

Although not largely produced in Cyprus, thanks to the exceptional quality of silk cocoons, silk and silk cocoons were also articles of export. While the export of silk cocoons was headed towards France, merchants from Beirut used to come over yearly to buy cocoons and stifle them with their small portable machines (Lang, 1878: 236). Although not much in quantity, local manufacture of silk was also worthy of attention, as far as the high quality of the articles are concerned. Accordingly, Savile reports that some very pretty light silk stuffs were manufactured in Nicosia by women, for dresses, scarfs, shirts, mosquito nets, and pocket-handkerchiefs; the latter being "especially good and considered equal to any made in France" (1878: 144-145).

Wine production played also considerable role in the external trade of the island. During the first decades of the second half of the $19^{\text {th }}$ century, annual production of wine was reported as around three millions of gallons. The exports of wine in 1861 and 1862 were respectively 707.000 and 824.940 gallons. As of 1878, all the exports headed towards Syria and Alexandria, except for a modest amount of famous Commandaria wine sent to Trieste (Lang, 1878: 228).

The fruit of the carob tree grown chiefly around Limassol, Larnaca and Kyrenia, was also a traditionally important article of export. Lang reports that, as of 1878 , the annual export was about 10.000 tons, heading mainly towards Russia, where it was highly esteemed and eaten as fruit (1878: 232-233).

Leather products were also traditional objects of trade which were drawing attention with their high quality, softness and brilliant colors. Accordingly, "very fine blue, yellow and red leathers were made for Turkish shoes and slippers, a considerable quantity of which was exported to Alexandria" (Savile, 1878: 144).

Another product crucial for island's foreign trade was salt, which was extracted from the Salt Lake nearby Larnaca. Salt production seems to have enormously increased during the $19^{\text {th }}$ century and as of 1878 , the yearly sales were about 12.000 tons (Lang, 1878: 260-261), exports targeting mainly the coasts of Syria.

Among other groups of products, sponges of all sizes and qualities sold to Syrian buyers (Savile, 1878: 145), as well as tobacco, linseed and sesame were worthy of mention, the latter referred to as of excellent quality and being exported chiefly to France (Lang, 1878: 228).

As shown by this short review of trade relations of the island, from the earliest periods of its history to the early modern period, Cyprus had always intense connections not only with its immediate surroundings in the Eastern Mediterranean, but also with western European trade centers. In geopolitical terms, as was the case during the late Middle Ages, towards the last quarter of the $19^{\text {th }}$ century, interest in Cyprus once again started to rise, perceived as a type of stepping stone by European powers, mainly France and Britain (Lang, 1878: 193). It is in this context that the strategic importance of the island came to the fore once more and with the British rule, the island once more became an extension - and periphery - of Northwestern Europe in the region.

After having reviewed the conceptual and historical background up until this point, it would be beneficial to refer back to the initial questions, namely: is the peripheralization of Cyprus with respect to the core area of Northwest Europe from early modern period onwards, different from the previous forms of peripherality of the island? If so, in which respects? Given the fact that this core-periphery dichotomy is still the case within the European integration as well, the island being classified as periphery, would it be necessary to revisit the essentials of the relationship of Cyprus with Europe, and eventually the island's Europeanness? The first part of these questions could be answered as follows: the island of Cyprus was located in the middle of several centers of gravity, which constantly interacted among each other for centuries. Among these, for most of the time Cyprus was an extension - or in a way periphery of the Aegean area. However, during this long period of pre-modern form of relative peripherality, island kept its 
central position with regard to its surroundings, as a self-sufficient and exporting economic unit, and as a point of transition on the major sea routes. Along with the general peripheralization of the Aegean and the Mediterranean from the early modern period onwards, the core area, to which the island depended, started to shift towards Northwest Europe. This time, nature of Cyprus's peripherality has also changed, involving differing production relations and fitting into the core-periphery dichotomy suggested by the world-system approach. This process came along with a certain detachment of the island from its surroundings in the Eastern Mediterranean. This detachment, which can be translated as a shift from connectivity to isolation was also exacerbated by the internal conflict on the island, which eventually led to its division.

The second part of the questions concerning the Europeanness of Cyprus will be discussed below under the next title. Such a discussion might be interesting not only because of the peripheral status of the island, but also because of the fact that the issue touches directly the (in)famous question of "where does Europe end?". For the sake of arguments held throughout these paper, it seems apt to re-formulate this question as "where does Europe extend to?"

\section{Cyprus and Europe: Where Does Continent [Ext]end [to]?}

Given the current situation and Cyprus's being part of the European integration, the questions of "what makes Cyprus European" and "where does Europe extend to?" seem at first sight quite obsolete and naive. However, some reasons make these questions, and especially the first one worthy to be addressed: firstly, the core-periphery setting imply an awkward relationship between Cyprus and Europe, which seems to continue; secondly the very fact that these questions have not been addressed so far, suggest that their answer, i.e. Cyprus's being European was taken for granted. It is for these reasons that the issue needs to be addressed, not to question Cyprus's being European or its EU affiliation, but to question the roots and nature of this identity.

Possible and alternative answers to the question "what Makes Cyprus European?" might be as follows: Hellenic Legacy, Christianity, Gothic Legacy, British Legacy and the EU dimension. In the light of the following quote from the relevant literature, which reflects a generally-accepted viewpoint, assessment of these probable answers is expected to become easier:

Cyprus has been part of this [european] heritage on many levels. First, the anthropological and ethnic origin of the country descends from the Mycenaeans, who first settled the island in the $16^{\text {th }}$ century BC spreading the Greek language and culture to the indigenous population. The island was also controlled by other European cultures such as the Romans (58 BC-AD 395), the Byzantines (395-1191), the English Crusaders (AD 1191), the French Lusignans (1192-1489) the Venetians (1489-1571) and the British Empire (1878-1960) who brought their own customs and traditions and influenced the fabric of the island's society (Sepos, 2008: 16).

Although classical Greece and Roman legacy are conventionally accepted as the primary sources of European culture, and although they are utilized as discursive tools to ground and construct the European identity, main concern of both the Hellenistic and Roman mentality was universality, rather than being confined to a certain geographical area as Europe. As a matter of fact, these cultures have flourished originally across the Aegean and the eastern Mediterranean world. Moreover, with the Christianity and especially upon the great schism between Catholicism and Orthodoxy, Eastern Orthodoxy developed an identity in opposition to western Catholicism, often inimically identified with "Europe". In Cyprus, it was the reflection of this identity that the "Frankish rule" (Frangokratia) has always remained alien and unpopular to local Greek Orthodox population of the island (Çevikel, 2006: 113-120, 130). Across the territories of the Eastern Roman (Byzantine) and Ottoman Empires, this identity was expressed

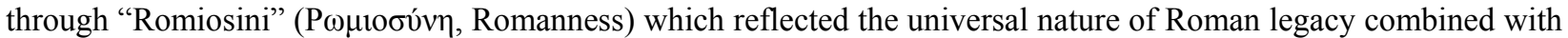
Orthodox Christianity. This legacy was also adopted also by the Ottoman rulers as "Rumîlik" (Romanness), this time mainly perceived as a geographical identity but still with reference to civilization and universality (Özbaran, 2004: 89-108). Thus, although ancient Greek or Hellenistic culture, Roman legacy, and Christianity have contributed to the emergence and development of the idea of Europe, they can hardly be identified with Europe itself. In so doing one would limit and distort the historical scope of these concepts, which are characterized by universality.

Thus, neither Greek, nor Roman cultures, nor Christianity can be referred to as sources for Cyprus's Europeanness, given that these elements are found elsewhere outside Europe originally and indigenously, and given that their main concern is universality. The remaining arguments are the medieval European rule on the island, which can roughly be referred to as the "Gothic legacy"; British rule and the ongoing European integration. Among these, the so-called Gothic legacy refers to the period starting with the crusades and ending with the Ottoman conquest of the island imprint of which is still visible in the architecture of the island. As known, rulers of the island during this period were originating mainly from Western Europe. The culture, architecture etc. they brought was originated in Western Europe. Needless to say, their existence on the island was at the expense of both Eastern Roman (Byzantine) and 
Ottoman powers, and the main function of the island during this period was rather a military outpost of Western Europe.

Although originating from Western Europe and despite its "Europeanizing" impacts on the island, British Empire was also something exceeding the scope of Europe, claiming global supremacy - if not universality. As far as the European integration is concerned, although it was initially economically motivated with only implicit political connotations, the Association Agreement signed in 1972 between the Republic of Cyprus and the EEC reflected strategic concerns of EEC (Christou, 2004: 62-63). To quote from Christou:

From the EEC perspective it made sense to draw Cyprus into the European club and make it economically interdependent. The reason for this however, was more strategic than economic from a European point of view. It had little to gain economically from Cyprus at that time, but the importance of attaining political stability in the region and the strategic importance of Cyprus as a bridge to the Middle East overrode any economic argument (2004: 63).

On the other hand, from 1970s onwards, despite its traditional non-aligned foreign policy, Greek Cypriots have started to perceive the European integration as a means for the re-unification of the island and settlement of the Cyprus problem (Sepos, 2008: 78). Therefore, the role of European integration was also politically-and-strategically-oriented both from the European and Greek - and later on Turkish - Cypriot sides.

Thus, given that the question of Europe's boundaries is a political one rather than geographical or historical, it might seem irrelevant to question Cyprus's European affiliation. But what might be worth discussing is the fact that from its initial phases onwards, sources of this affiliation originate from political-strategic concerns developed mostly in conflict-stricken contexts. Consequently, the island remains peripheral and much less central than ever.

\section{Conclusion}

As an insular setting with sui generis characteristics, essentials of Cyprus's economic geography have been formed through the maritime networks linking the island to the major centers of gravity. Located around itself, these were Mesopotamia (including the Fertile Crescent area), Egypt and the Aegean basin (involving a wide area extending from South Italy to inner parts of Anatolia), which interacted among each other. For most of the time, Cyprus was part - or in a way periphery of the Aegean basin. However, this pre-modern type of relative peripherality did not prevent the island from retaining its central position in the Mediterranean as a self-sufficient and exporting economic unit, and as a point of passage on the major sea routes.

Due to the general peripheralization of the Mediterranean in the sense suggested by the world-system approach, from early modern period onwards, core area, to which the island depended, shifted towards Northwest Europe. Due to this shift, nature of island's peripherality has also evolved, involving differing production relations between the core and the periphery. Reverberations of this setting still seem to be effective in the context of the European integration, especially as far as the north-south division or the "Mediterranean dimension" is concerned.

This setting paves the way to question Cyprus's position with regard to Europe. Especially in the context of the European Integration, of which the island has been part for over a decade now, the relationship of Cyprus with Europe seems natural and clear. But one should not lose sight of the fact that, the island's position with regard to Europe and its European affiliation have been formed within the center- or core-periphery context. What is more, sources of this affiliation originate mostly from political and strategic - rather than economic - concerns, developed mainly in conflict-stricken contexts. As a result of this relationship, the island remains peripheral with regard to Europe and much less central than ever with regard to both its immediate surroundings as well as to the wider Mediterranean context.

\section{References}

Baker, S.W. (1879). Cyprus as I Saw It in 1879. London: Macmillan and Co.

Braudel, F. (1972). The Mediterranean and the Mediterranean World in the Age of Philip II. Vol. 1. New York: Harper and Row.

Braudel, F. (1999). La Méditerranée l'Espace et l'Histoire, Paris: Flammarion.

Broodbank, C. (2000). An Island Archaeology of the Early Cyclades. Cambridge: Cambridge University Press.

Brown, C. (1997). Understanding International Relations. London: Macmillan.

Brown, H.F. (1887). Venetian Studies. London: Kegan Paul \& Trench.

Çevikel, N. (2006). Kıbrıs'ta Osmanlı Mirası (1570-1960). Istanbul: 47 Numara Yayıncılık.

Christou, G. (2004). The European Union and Enlargement, The Case of Cyprus. Hampshire: Palgrave. 
Constantakopoulou, C. (2007). The Dance of the Islands: Insularity, Networks, The Athenian Empire, and the Aegean World. Oxford: Oxford University Press.

Demand, N. (2004). Iron Age Cyprus: Recent Finds and Interpretative Strategies. In R. Rollinger \& C. Ulf (Eds.), Commerce and Monetary Systems in the Ancient World: Means of Transmission and Cultural Interaction (pp. 257-269). Munich: Franz Steiner Verlag.

Fisher, F. (1878). Cyprus, Our New Colony and What We Know about It. London: George Routledge and Sons.

Grether, J.M., \& Mathys, N. (2009). Is the World's Economic Centre of Gravity already in Asia? Area, 42(1), 47-50.

Hadjisavvas, S. (2007). The Public Face of the Absolute Chronology for Cypriot Prehistory. In M. Bietak \& E. Czerny (Eds.), The Synchronisation of Civilisations in the Eastern Mediterranean in the Second Milennium BC III. Vienna: Österreichische Akademie der Wissenschaften.

İnalcık, H. (2012). Osmanlı Döneminde Balkanlar Tarihi üzerinde Yeni Araştırmalar. Ankara Üniversitesi Güneydoğu Avrupa Çalışmaları Araştırma ve Uygulama Merkezi Dergisi, (1), 1-10.

Insular. (1996). Webster's Encyclopedic Unabridged Dictionary of the English Language (p. 737). New York: Gramercy Books.

Isolation. (1996). Webster's Encyclopedic Unabridged Dictionary of the English Language (p. 756). New York: Gramercy Books.

Knapp, B. (2008). Prehistoric and Protohistoric Cyprus, Identity, Insularity and Connectivity. New York: Oxford University Press.

Koliopoulos, J. S., \& Veremis, T. M. (2010). Modern Greece A History since 1821. West Sussex: Wiley-Blackwell.

Lang, H. (1878), Cyprus, Its History, Its Present Resources, and Future Prospects. London: Macmillan and Co.

Love, J. (1980). Raùl Prebisch and the Origins of the Doctrine of Unequal Exchange. Latin American Research Review, 15(3), 45-72.

Luke, H. C. (1921). Cyprus under the Turks, 1571-1878 A Record Based on the Archives of the English Consulate in Cyprus under the Levant Company and After. London: Oxford University Press.

Özbaran, S. (2004). Bir Osmanlı Kimliği, 14-17. Yüzyıllarda Rûm/Rûmi Aidiyet ve İmgeleri. Istanbul: Kitap Yayınevi.

Özkul, A. E. (2010). Kıbrıs'ın Sosyo-Ekonomik Tarihi (1726-1750). Ankara: Dipnot.

Pirî Reis. (2002). Kitab-ı Bahriye (2 ${ }^{\text {nd }}$ ed.). Ankara: Türk Tarih Kurumu.

Quah, D. (2010). The Shifting Distribution of Global Economic Activity. LSE Economics Department Paper. Retrieved from http://econ.lse.ac.uk/ dquah/p/2010.05-Shifting_Distribution_GEA-DQ.pdf

Quah, D. (2011). The Global Economy's Shifting Centre of Gravity. Global Policy, 2(1). 3-9.

Raaflaub, K. (2004). Archaic Greek Aristocrats as Careers of Cultural Interaction. In R. Rollinger \& C. Ulf (Eds.), Commerce and Monetary Systems in the Ancient World: Means of Transmission and Cultural Interaction (pp. 197-217). Munich: Franz Steiner Verlag.

Savile, A. (1878). Cyprus. London: Her Majesty's Stationery Office.

Sepos, A. (2008). The Europeanization of Cyprus, Polity Policies and Politics. Hampshire: Palgrave.

Wallerstein, I. (1974a). The Modern World-System I: Capitalist Agriculture and the Origins of the European World-Economy in the Sixteenth Century. New York: Academic Press.

Wallerstein, I. (1974b). The Rise and Future Demise of the World-Capitalist System: Concepts for Comparative Analysis. Comparative Studies in Society and History, 16, 387-415.

Wallerstein, I. (2006). World Systems Analysis: An Introduction. Durham: Duke University Press.

Wood, A. C. (1964). A History of the Levant Company. Oxon: Oxford University Press.

\section{Notes}

Note 1. It should be noted that both the words "insularity" and "isolation" derive from the same root in Latin "insula" meaning "island" (Webster's Encyclopedic Unabridged Dictionary of the English Language, Gramercy Books, New York 1996).

Note 2. See for instance the critical observations of Sir Samuel W. Baker on the self-sufficiency of the island during the first years of the British rule: Samuel W. Baker, Cyprus as I Saw It in 1879, Macmillan and Co., London 1879, pp. 437-438. 